\title{
Trichloroethanol in Trichloroethylene Poisoning
}

\author{
H. MIKISKOVÁ and A. MIKISKA \\ From the Institute of Industrial Hygiene and Occupational Diseases, Department of Physiology \\ of Higher Nervous Functions, Srobarova 48, Praha 10, Czechoslovakia
}

Trichloroethylene and trichloroethanol were given intraperitoneally to guinea-pigs. Their effects were tested by measuring the threshold current intensity of electrical skin stimulation, the electrical excitability of the motor cerebral cortex, by recording and analysis of the electroencephalogram, and by electrocardiographic examination. The two compounds had similar effects on the nervous system and the heart, but trichloroethanol was the more effective by a factor of at least three. These results support the opinion of clinical investigators on the important role of trichloroethanol in the pathogenesis of trichloroethylene poisoning.

Trichloroethylene is a compound of considerable interest to both the pharmacologist and toxicologist because of its widespread uses as a general anaesthetic and as an industrial solvent and detergent. Unlike many other inhalation anaesthetics, trichloroethylene is retained and metabolized in the body in considerable amounts, depending on the length of exposure and vapour concentration. In conditions similar to those of occupational exposure as much as one half may be retained and metabolized.

The following metabolites of trichloroethylene (TRI) have been identified: (a) trichloroacetic acid (TCA), in dogs by Barrett, Cunningham, and Johnston (1939), and in man by Powell (1945); (b) trichloroethanol (TCE), eliminated mostly as urochloralic (trichloroethyl- $\beta$-d-glucuronic) acid, identified in dogs by Butler (1949), and in man by Souček and Vlachová (I954); (c) monochloroacetic acid, and $(d)$ chloroform; both identified in humans by Souček and Vlachová (1954, 1960).

Butler (1948, 1949) first drew attention to the fact that trichloroethylene gives the same terminal metabolic products as chloral hydrate, and he advanced the hypothesis that chloral hydrate is the intermediary product in trichloroethylene metabolism. This metabolic scheme has been accepted by many other workers who have supplemented it with other newly discovered metabolites (Souček and Vlachová, 1954, 1960), examined the reaction mechanisms (Bardoděj and Vyskočil, 1956), or studied the modification of trichloroethylene metabolism by disulfiram, fructose, and lactic acid (Bartoníček and Teisinger, 1962).

Received for publication November 24, 1964 .
The ratio of the amounts of trichloroethanol and trichloroacetic acid excreted in the urine is dependent on the degree of trichloroethylene exposure and on the animal species. In humans and dogs with low or moderate exposure this ratio, TCE : TCA, varies usually from one to three (Bardoděj and Krivucová, I958; Medek, I958; Souček and Vlachová, 1960). In some animal species, e.g., rabbits, and in highly exposed man the ratio may rise to several hundreds (Přerovská, Srbová and Stýblová, 1958; Bartoniček and Souček, 1959).

A schematic representation of trichloroethylene metabolism is presented in Fig. IA, in which the thickness of the arrows is approximately in proportion to the amounts of metabolites formed in humans or dogs with low or moderate exposures. Those substances accumulating in the organism in appreciable quantities but mostly transformed further are designated by single frames. The substances eliminated in the expired air or urine (trichloroethylene itself and the principal terminal metabolites) are denoted by double frames.

Another hypothesis on the sequence of metabolic steps has been suggested by Forssman, OweLarsson, and Skog (1955) and is shown in Figure IB. According to this hypothesis the intermediary product in the metabolic conversion of trichloroethylene to trichloroacetic acid is trichloroethanol.

The known trichloroethylene metabolites possess their own pharmacodynamic action. The central nervous depressant action of trichloroethanol was discovered by Külz as early as I884 and was confirmed by Butler (1948), Marshall and Owens (1954), and Owens, Marshall, Broun, Zubrod, and Lasagna (1955). Trichloroethanol does not lose I6 
FIG. I. Trichloroethylene metabolism: A, according to Butler (1949), Souček and Vlachová (1954, 1960), Bardoděj and Vyskočil (1956), and Bartoníček and Teisinger (1962); B, according to Forssman et al. (1955).

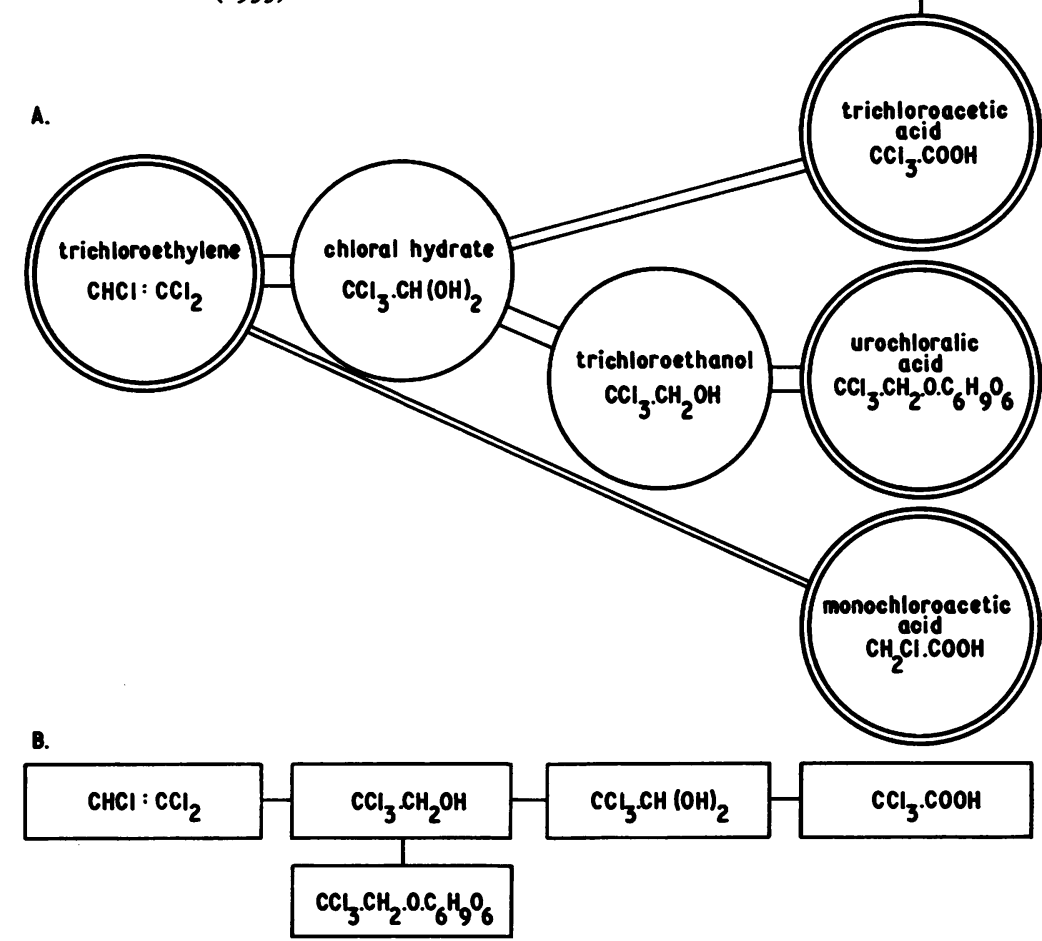

completely its central nervous depressant action even when it is conjugated with glucuronic acid (Külz, 1884). This conjugation is very probably reversible, and free trichloroethanol may be formed from administered urochloralic acid. Also trichloroacetic acid was shown to possess a light hypnotic action (Woodard, Lange, Nelson, and Calvery, 194I; Paykoç and Powell, 1945). This is probably due to TCA itself because metabolic transformation of TCA to trichloroethanol or chloral hydrate has never been observed.

Monochloroacetic acid lacks any hypnotic or narcotic action; but choleretic and laxative action as well as marked hepatotoxicity at higher doses were observed (Woodard et al., I94I).

Toxicological data about these compounds were published by Woodard et al. (194I), Marhold (1953), Souček and Vlachová (1959), and Bardoděj (1963). The toxicity of trichloroacetic acid is low, so :hat it is highly improbable that it plays any part in trichloroethylene intoxication. The toxicity of monochloroacetic acid is relatively high, so that this substance may participate; but no experimental evidence of this has been given so far.

Unfortunately no comparison of the toxicity of trichloroethylene itself with that of its metabolites (especially trichloroethanol) is possible on the basis of the work summarized. Either the toxicity of trichloroethylene has not been studied at all, or it has been investigated only for inhalation exposure, so that the amount of absorbed trichloroethylene is not known (data compiled by Bardoděj, 1963).

An attempt to elucidate the role of trichloroethylene metabolites was made by Přerovská $e t$ al. (1958). These authors studied the excretion of trichloroethanol and trichloroacetic acid in patients with acute oral trichloroethylene intoxication. In the first one or two days of intoxication large amounts of trichloroethanol are excreted in the urine, while the excretion of trichloroacetic acid is 
many times lower. By the third or fourth day of intoxication the rate of excretion of trichloroethanol is already greatly decreased, while the excretion of trichloroacetic acid reaches its maximum. These variations in excretion are well correlated with the clinical state of the patient: the deepest state of unconsciousness coincides with the maximum concentration of trichloroethanol in the urine; and recovery of consciousness coincides with maximal elimination of trichloroacetic acid. Přerovská et al. (1958) concluded from these observations that the narcotic state of the intoxicated patient is due not only to trichloroethylene but also to trichloroethanol formed in the course of metabolism.

We have therefore compared the narcotic action of trichloroethylene and trichloroethanol by several electrophysiological methods.

\section{Methods}

Both substances were injected intraperitoneally into guinea-pigs.

Spinal Reflex Excitability This was tested by measuring the threshold current intensity evoking a defensive reaction to skin stimulation. A constantcurrent output stimulator was used, so that the current intensity did not depend on the resistance of the skin and electrodes. The animal was held by the experimenter so that it touched the stimulating electrodes with its hind paws. The threshold reaction-minimal dorsal flexion of the toes-was observed and evaluated visually. The threshold current intensity was compared in groups of control animals and animals injected with the drug-15 to 25 guinea-pigs for each dose and the same number of controls. The method was described by Mikisková and Mikiska (1962), who also presented evidence that it tested changes in spinal reflex excitability. The depth of narcosis was determined only at its estimated highest level, i.e., Io to $15 \mathrm{~min}$. after injection of trichloroethanol or 20 to $30 \mathrm{~min}$. after injection of trichloroethylene.

Electrical Excitability of the Motor Cerebral Cortex This was determined by means of implanted epidural electrodes by measuring the threshold voltage of rhythmic stimulation evoking minimal movement of the contralateral fore-limb (Mikiska, 1960).

Electroencephalographic Recordings Recordings were taken from epidural electrodes implanted over the motor area of the cerebral cortex using a bipolar lead with a short inter-electrode distance. The E.E.G. signal was processed by an electronic integrator (Mikiska, 1963) and stored on the magnetic tape simultaneously with the recordings. The magnetic tape was used for subsequent frequency analysis. Our frequency modulation system of E.E.G. tape recording was described by Mikiska (I962).

Electrocardiogram A three-dimensional system of leads was used, a modification of Wilson, Johnston and Kossman's (1947) system of spatial vectorcardiography. Three-dimensional electrocardiography enables us to differentiate real changes in amplitude of E.C.G. waves from changes caused by rotation of the electrical heart axis.

Further details on the technique of E.E.G. and E.C.G. recording and analysis in guinea-pigs together with the data on normal tracings in this species have been published elsewhere (Mikiska and Mikisková, 1964).

In these three types of experiment the time course of the effects was followed until the effects had disappeared, usually $3 \mathrm{hr}$. after injection but sometimes longer. Only one dose of each drug was tested, $6.7 \mathrm{mM}$. of trichloroethylene $/ \mathrm{kg}$. ( $0.6 \mathrm{ml}$., $0.88 \mathrm{~g}$.), and $2.2 \mathrm{mM}$. of trichloroethanol $/ \mathrm{kg}$. $(0.22 \mathrm{ml}$., $0.34 \mathrm{~g}$.). Controls were given 0.3 to $0.4 \mathrm{ml}$. of physiological saline. Electroencephalographic and electrocardiographic changes were usually studied simultaneously in the same animal. The electrical excitability of the cerebral cortex was studied in other experiments in order to prevent modification of E.E.G. and E.C.G. patterns by cortical stimulation. Experiments were carried out on groups of five to eight guinea-pigs.

\section{Results}

Symptomatology After intraperitoneal administration of $6.7 \mathrm{mM} . / \mathrm{kg}$. trichloroethylene, general anaesthesia, characterized by loss of muscular tone, depression of righting reflexes, slowing of respiration, but not by disappearance of the corneal reflex, developed within I5 to $30 \mathrm{~min}$. and lasted usually 2 to 3 hours. Injection of $2 \cdot 2 \mathrm{mM}$. $/ \mathrm{kg}$. trichloroethanol was followed by anaesthesia within 5 to ro minutes. Anaesthesia was usually deeper, with depression of the corneal reflex in about one half of the experiments, but lasted a shorter time, as a rule 45 to 60 minutes.

During recovery from anaesthesia behaviour became normal sooner than electrical excitability or spontaneous electrical activity of the central nervous system ( $c f$., the following results).

During the light stages of anaesthesia some animals moved frequently in attempts to correct their posture. Convulsions and paroxysmal E.E.G. patterns were not observed. No deaths occurred during anaesthesia but several hours after injection symptoms of subacute intoxication developed in a small proportion of animals given $6.7 \mathrm{mM}$./kg. trichloroethylene and in almost all the animals given $2.2 \mathrm{mM}$. $/ \mathrm{kg}$. trichloroethanol. The symptoms (decrease of muscular tone, ataxia, and hyperalgesia) have already been described (Mikisková and Mikiska, 1960) and will be analysed in another paper.

The administration of smaller doses of trichloroethylene and trichloroethanol caused only brief light general anaesthesia without any apparent sequelae. 

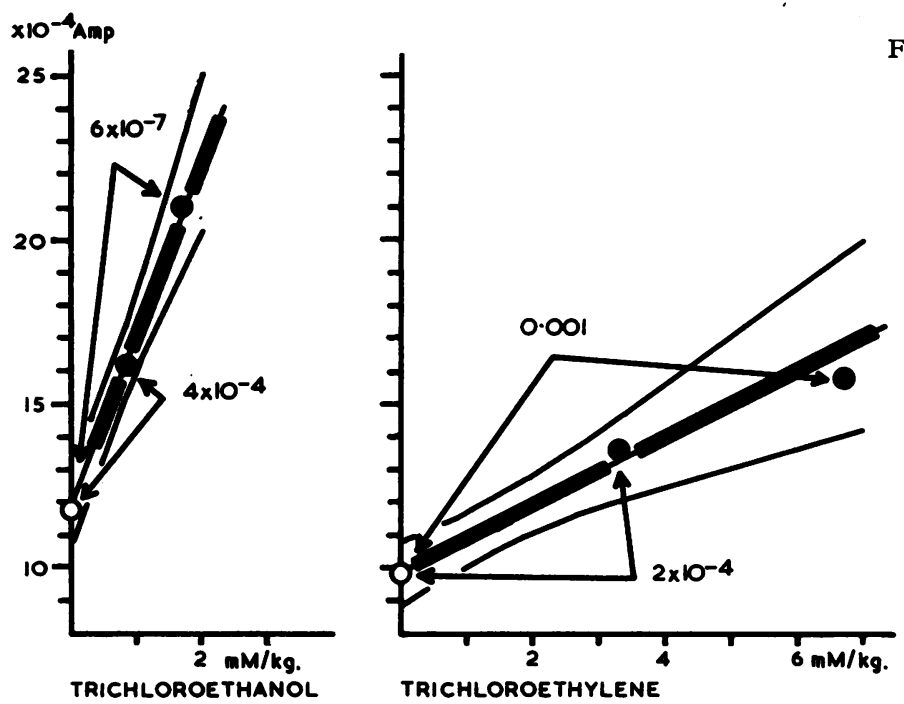

FIG. 2. Action of trichloroethylene and trichloroethanol on the threshold current intensity of skin stimulation. Mean values for controls $(O)$ and for experimental animals $(O)$. Best straight lines with fiducial belts $(P=0.05)$ are shown, and also the significance of differences between means for experimental and control animals.

Measurement of Threshold Current Intensity Evoking Defensive Reactions to Electrical Skin Stimulation The depressant action of general anaesthetics manifests itself by an increase in the threshold intensity of stimulus which is approximately proportional to the dose up to that which results in complete abolition of spinal reflex excitability. One can therefore take the slope of the threshold intensity-dose graph as a measure of central nervous depressant action. The results are shown in Figure 2. All doses raised the threshold significantly as shown by the values of $P$ in Figure 2 (calculated by the non-parametric Mann-Whitney one-tailed test). The regression lines and their fiducial belts $(P=0.05)$ are also shown. ${ }^{\star}$ The ratio of the slopes, TCE : TRI, is 5.2 , fiducial limits 3.2 to $9 \cdot 6$, i.e., intraperitoneal trichloroethanol has an effect about $5 \cdot 2$ times greater than the same dose of trichloroethylene.

Electrical Excitability of Cerebral Motor Cortex The threshold voltage was measured before and after injection, and the increase as a percentage of the pre-injection value was taken as a measure of central nervous depressant action. In Fig. 3A the square root $\dagger$ of threshold voltage increase is plotted against time from injection. Average values \pm standard errors of means are shown, computed from six experiments with each drug.

From Fig. 3A it appears that the central nervous

${ }^{\star}$ Regression lines were computed and evaluated by Ing. $Z$. Roth. depressant action of trichloroethanol is much greater than that of trichloroethylene. The depressant action of trichloroethylene on the cerebral motor cortex does not disappear in the third hour after injection but is approximately the same as during the first hour. Trichloroethylene differs in this respect from other narcotic solvents tested in our laboratory, e.g., aromatic hydrocarbons (Mikisková, 1960; Mikisková and Mikiska, 1960).

The square root of the threshold voltage increase after the administration of trichloroethanol was more than twice as high as that after trichloroethylene. Taking into account that the dose of trichloroethanol was one-third of that of trichloroethylene, we may conclude that trichloroethanol is about six times more depressant than trichloroethylene, in accord with the relative effects obtained by measuring the spinal reflex excitability.

Recording and Analysis of Electroencephalogram In the normal electroencephalo-

$\dagger$ The effect (E) of general anaesthetics as well as of other drugs with a low ratio of the toxic to therapeutic dose may often be described by the function of the dose (D): $\mathbf{E}=$ const. $\mathrm{D}^{\alpha}$. This result is not in disagreement with the generally accepted view that the dose-effect curve usually has a sigmoid shape; only the initial segment of the sigmoid curve may be observed for drugs with a low 'therapeutic index'. For the functional dependence of the relative increase in cortical motor threshold on the dose of a general anaesthetic the value of the exponent, $\alpha$, was close to 2 (Králová, Mikiska, and Paŕizek, 1957; Mikisková, 1960), so that the dose and the square root of the threshold voltage increase should be related linearly. For other effects, $\alpha=1$, as: e.g., in the preceding section. 

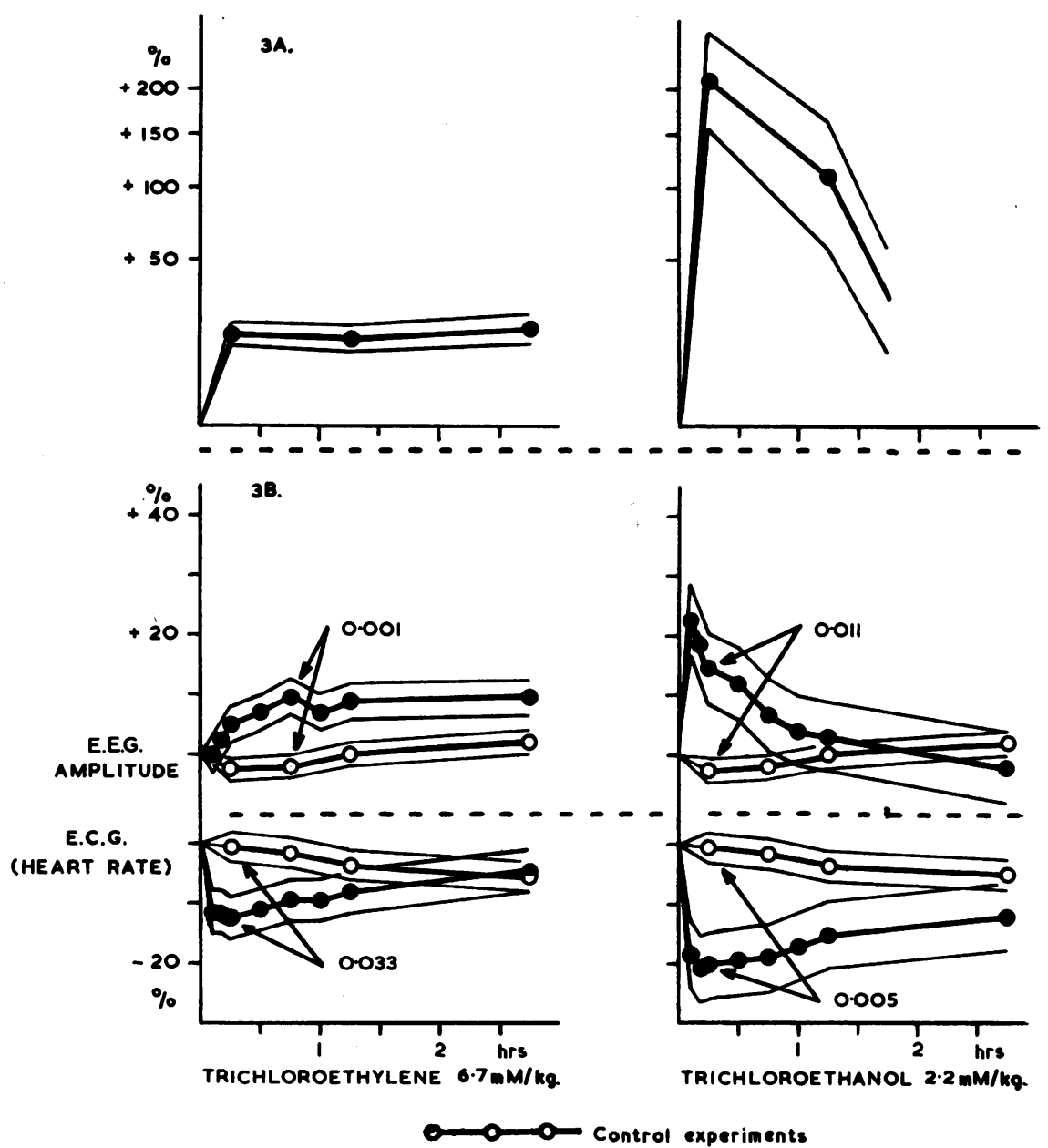

Fig. 3. Action of trichloroethylene and trichloroethanol on: A, threshold of electrical excitability of the motor cerebral cortex; B, E.E.G. amplitude and heart rate. Conventions as in Fig. 2, except that the belts shown represent S.E.s and not fiducial limits.

gram of a waking guinea-pig recorded bipolarly from the motor area of the cerebral cortex, fast rhythms in the alpha and beta range usually dominate. Sometimes, however, a dominant frequency in the theta range may be present. E.E.G. patterns of light physiological sleep are sometimes observed, appearing as random regular spindles, $14 \mathrm{c} / \mathrm{s}$.

After trichloroethylene or trichloroethanol the following E.E.G. changes were observed: $\ddagger$

I. A stage of 'cortical E.E.G. desynchronization', corresponding to the 'fast' stage of Bickford and Faulconer (196I). This stage was only transitory in our experiments. The E.E.G. amplitude was decreased by not more than 10 to $15 \%$ and this decrease could be detected during induction of anaesthesia in only two out of five experiments with trichloroethylene and in none with trichloroethanol.

II. A stage of random spindles and/or slow waves.

III. A stage of continuous slow waves and/or

¥The designation of E.E.G. stages of anaesthesia by Roman numbers is identical with that used by Courtin (1955) and Martin, Faulconer, and Bickford (1959) for trichloroethylene anaesthesia (with the exception of stage II, which is quite different when trichloroethylene is administered by injection instead of by inhalation). It should not be confused with Guedel's (195I) classification of anaesthesia depth based on clinical symptomatology. 
spindles, corresponding to the ' $D$ ' stage of physiological sleep or to the 'complex' stage of Bickford and Faulconer (196I).

IV. The 'burst suppression' stage of Bickford and Faulconer, i.e., E.E.G. activity appearing as bursts of high voltage waves, mainly slow, separated by sections of E.E.G. tracing, consisting only of low voltage slow activity.

Of five experiments with trichloroethylene, the E.E.G. stage at the maximal depth of anaesthesia was II in three experiments, and III in two experiments. In six experiments with trichloroethanol at the maximal depth of anaesthesia, stage III was observed in five experiments and stage IV in one experiment.

The E.E.G. amplitude, which was decreased during stage $I$, increased again as anaesthesia moderated. It is therefore possible to take the increase in E.E.G. amplitude with respect to its pre-injection value as a measure of anaesthesia depth, if the "burst suppression" stage or the stage of complete suppression of E.E.G. activity is not reached.

In Fig. 3B the increase in E.E.G. amplitude as a percentage of its pre-injection value is plotted against the time elapsed from the injection. Average values \pm standard errors of means were computed for trichloroethylene and trichloroethanol experiments and for controls. The significance was tested by Mann-Whitney's rank statistics for two samples of independent observations (one-tailed test).

It appears from Fig. 3 that the time course of the increase in E.E.G. amplitude and the relative effects of trichloroethylene and trichloroethanol are similar to the changes in the threshold of excitability of the cerebral motor cortex.

Frequency analysis of E.E.G. records in the stages 'random spindles and/or slow waves' and 'complex' reveals a great prevalence of delta and theta frequency components. Statistical evaluation of the results of frequency analysis is much more difficult than that of E.E.G. integration due to the overwhelming number of numerical data and great differences in the frequency spectra of individuals.

Figure 4 shows the E.E.G. of a guinea-pig before and after intraperitoneal injection of $6.7 \mathrm{mM}$./kg. trichloroethylene recorded at a paper speed of $3 \mathrm{~cm}$. $/ \mathrm{sec}$. Figure 5 presents a similar record for $2 \cdot 2 \mathrm{mM}$./kg. trichloroethanol recorded at a paper speed of $6 \mathrm{~cm}$. $/ \mathrm{sec}$. Both figures show the E.E.G. 'complex' stage at the highest level of anaesthesia. A figure demonstrating the E.E.G. 'burst suppression' stage after injection of trichloroethanol was published previously (Mikisková and Mikiska, 1960).

Electrocardiographic Examination The heart rate in normal guinea-pigs tied to the fixation table varies between 240 and 360 beats per minute.
500

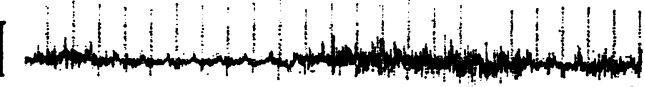

500

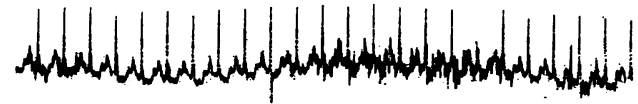

500

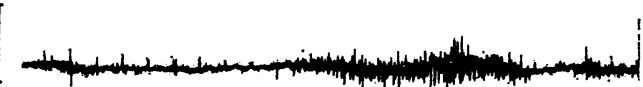

N

50
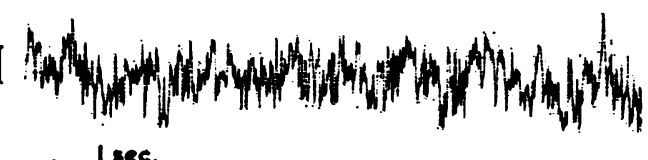

$$
\text { I ses. }
$$

100
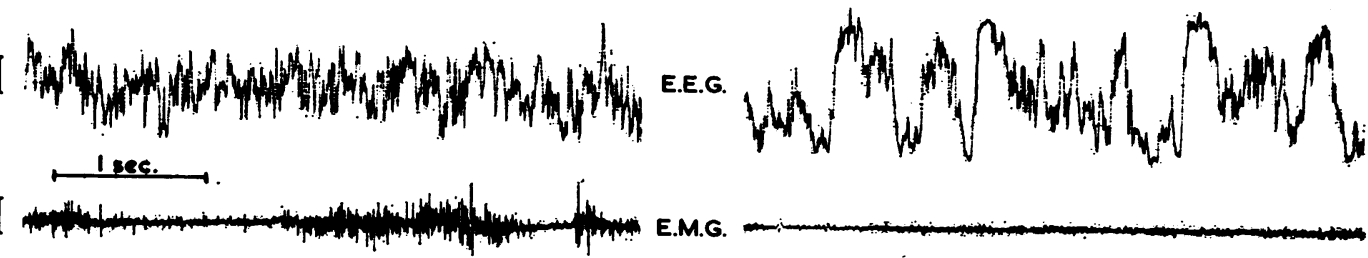

FIG. 4. Action of trichloroethylene on E.C.G., E.E.G., and summation E.M.G. E.C.G. leads I, VF, and BV according to Wilson et al. (1947) are used. E.E.G. was recorded from the motor cerebral cortex. E.M.G. potentials were led off from clip electrodes attached to both hind limbs. Left tracings: control record before injection. Right tracings: record 15 min. after intraperitoneal injection of $6.7 \mathrm{mM}$. $/ \mathrm{kg}$. trichloroethylene. 


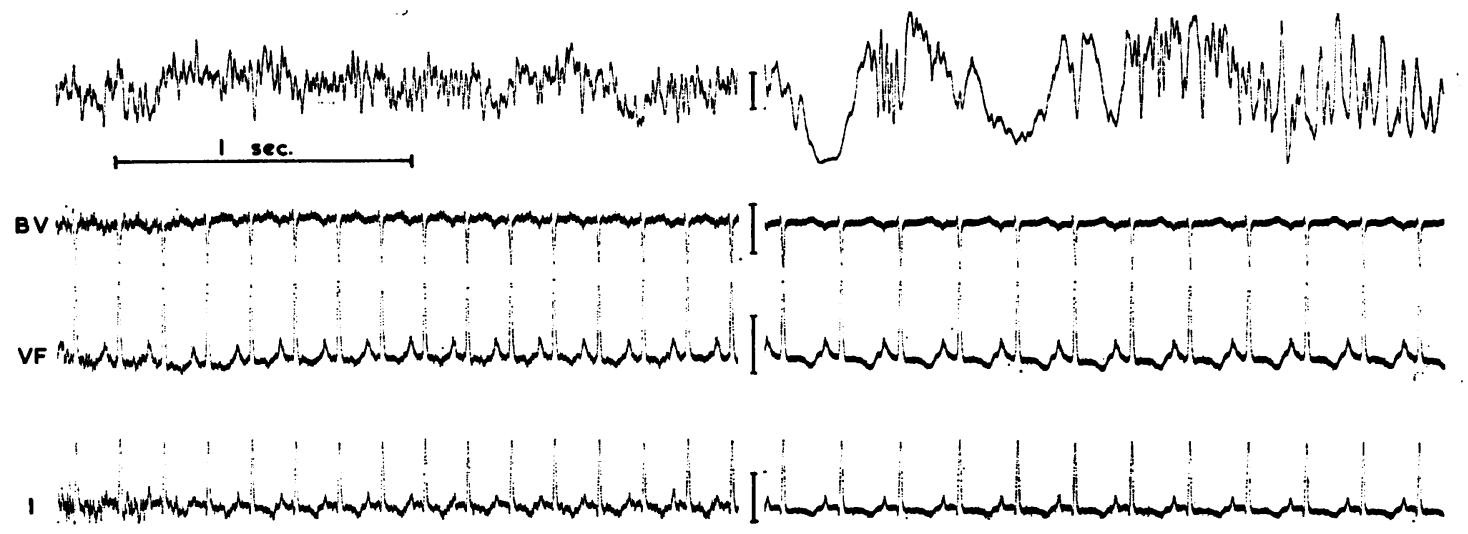

FIG. 5. Action of trichloroethanol on E.E.G. and E.C.G. Left tracings: control record before injection. Right tracings: record $15 \mathrm{~min}$. after intraperitoneal injection of $2 \cdot 2 \mathrm{mM}$. $/ \mathrm{kg}$. trichloroethanol. A paper speed of $6 \mathrm{~cm}$. $/ \mathrm{sec}$. was used for recording this section of tracings to show the E.C.G. waveform more distinctly. Calibration as in Fig. 4.

In about $5 \%$ of animals a pronounced sinus arrhythmia independent of respiration is observed. Still more rarely single ventricular extrasystoles may be seen in the E.C.G.

The following changes in the E.C.G. were observed after trichloroethylene or trichloroethanol: slowing of the heart rate, slowing of the atrioventricular transmission of excitation, i.e., lengthening of the interval $P Q$, and lengthening of the repolarization phase of electrical systole of the ventricles, i.e., the interval ST. With the doses used in our experiments we have never observed cardiac arrhythmias nor changes in the complex QRS. Only in one experiment with trichloroethanol did a marked modification of the $T$ wave occur, i.e., inversion and sharpening in all leads. This change was probably anoxic in origin, since the respiration rate was slowed more than $70 \%$.

Examples of a normal E.C.G. tracing and of E.C.G. changes after trichloroethylene and trichloroethanol administration are shown in Fig. 4 and in greater detail in Figure 5.

In the lowest part of Fig. 3 changes in the heart rate are plotted against the time elapsed from injection. (The heart rate was decreased, therefore the ordinates are negative.) The arrangement of this graph is similar to that concerning E.E.G. amplitudes.

As can be seen from Fig. 3, the decrease in the heart rate after $2.2 \mathrm{mM}$./kg. trichloroethanol was almost twice as great as that after $6.7 \mathrm{mM}$. $/ \mathrm{kg}$. trichloroethylene, i.e., the relative effects of trichloroethylene and trichloroethanol on the heart rate were similar to those on the E.E.G. amplitude or on the threshold of electrical excitability of the cerebral motor cortex.
The time course was, however, somewhat different: by the third hour after injection of trichloroethylene the heart rate had in most experiments completely recovered. In other words, the recovery of the heart rate followed behavioural recovery more closely than restitution of the cortical electrical excitability or the E.E.G.

In some of our experiments one channel of the recorder was used for registration of the summation electromyogram; and in other experiments the movements of the animal could be evaluated from electromyographic activity appearing in the E.C.G. leads (Figs. 4 and 5). At the highest level of anaesthesia this electromyogram activity disappeared completely or almost completely. Its recovery followed closely behavioural recovery and restitution of the heart rate.

\section{Discussion}

The effects of trichloroethylene anaesthesia on the electroencephalogram have been studied in human subjects (Gibbs, Gibbs, and Lennox, 1937; Schneider, 1954; Courtin, I955; Okuma, Shimazono, and Narabayashi, 1957) as well as in animals (Beecher and McDonough, 1939; Horváth and Mikiska, 1957; Schlag and Brand, 1958; Domino and Ueki, 1959; Serra and Ambrosio, 1961; Desoille, Pinchon, Lille, and Bourguignon, 1962a; Desoille, Pinchon, Jans, and Bourguignon, I962b). A review of these findings and a comparison of them with our results is beyond the scope of the present paper. In general we can state that E.E.G. changes in humans and in various animal species during general anaesthesia or acute poisoning with trichloroethylene are very similar to those evoked by 
other volatile anaesthetics, the differences (observed by some authors only) being of minor importance.

Electroencephalographic findings in chronic trichloroethylene poisoning (Rubino, Scansetti, and Trompeo, 1949; Andersson, 1957; Roubíček, 1959; Massignan and Picotti, 1955; Serra and Ambrosio, 196I; Picotti and Brugnone, 1962; Chalupa, Synková, and Sevčik, 1960; Klimková-Deutschová, Macek, and Roth, 1959; Roth and KlimkováDeutschová, 1964; Stýblová, 1965) reflect metabolic damage to the central nervous system outlasting the direct action of the poison rather than anaesthetic or hypnotic action of trichloroethylene or its metabolites.

As far as the effect of trichloroethylene on the electrocardiogram is concerned, rodents appear to be less prone to develop cardiac arrhythmias than humans or dogs (Barnes and Ives, 1944; Orth and Gillespie, I945; Ostlere, I953; Atkinson, 1960; Defalque, I96I). Bradycardia and various degrees of heart block are the most striking features in rabbits or guinea-pigs (Mallach, Marquardt, and Werch, 1943; Waters, Orth, and Gillespie, 1943; Bose and Mukerii, 1944). It is worth mentioning, however, that in oral intoxication with trichloroethylene E.C.G. patterns similar to our findings in guinea-pigs may be found even in humans (Stentiford and Logan, 1956), and that cardiac arrhythmia after oral trichloroethylene is sometimes directly related to airway obstruction (Dhunér, Nordquist, and Renström, 1957).

We do not know of any references to the effect of trichloroethanol on the E.E.G. or E.C.G. except our own pilot study (Mikisková and Mikiska, 1960).

From our results on guinea-pigs we can conclude that trichloroethylene and trichloroethanol, injected intraperitoneally, do not differ qualitatively in any way in their effects on the four electrophysiological responses studied, but that trichloroethanol is at least three and probably five to six times the more effective at the same injected dose.

Differences in effectiveness between various substances injected in equal doses may be due either to the difference in effectiveness of similar tissue concentrations or to the difference in resulting tissue concentrations caused by differences in resorption rate, in distribution between various organs, and in rates of elimination. We shall discuss the probable role of these factors for trichloroethylene and trichloroethanol.

The rate of absorption from the peritoneal cavity does not seem to be an important factor in our experiments. Both substances are rapidly absorbed after intraperitoneal injection, like other lipidsoluble general anaesthetics. For trichloroethanol this is shown by the rapid onset of anaesthesia. The absorption rate of trichloroethylene may have been somewhat slower, because the quantity of injected liquid was larger; but we could prove that even $27 \mathrm{mM}$. $/ \mathrm{kg}$. trichloroethylene, i.e., four times the usual dose, was completely absorbed from the peritoneal cavity within one hour.

For tissue distribution, too, there is no reason to believe that important differences exist between trichloroethylene and trichloroethanol. Analytical estimations of tissue distribution have been carried out only for trichloroethylene (see review by Bartoniček and Souček, I959), but the distribution of trichloroethanol is probably very similar, since both substances have similar solubilities in both water and lipids.

On the other hand, there is a substantial difference between the proportions of trichloroethylene and trichloroethanol exhaled, elimination with the expired air being quantitatively more important for trichloroethylene (boiling point $87^{\circ} \mathrm{C}$.) than for trichloroethanol (boiling point $150^{\circ} \mathrm{C}$.).

In humans given trichloroethanol or chloral hydrate orally, no exhalation of trichloroethanol could be demonstrated even by a refined analytical technique (Bardoděj, 1963). Bartoniček and Souček (1959) estimated that of trichloroethylene injected intramuscularly into rabbits about $65 \%$ was retained. In our experiments the retention of trichloroethylene, administered intraperitoneally, was probably at least as great, since retention of any volatile substance injected intraperitoneally is higher than after intramuscular or subcutaneous injection, because much of the substance is absorbed into the blood of the portal vein and is stored in the liver, so that a lower concentration appears in the lung circulation.

These considerations suggest that the retention of trichloroethylene in our experiments was at least one half of the injected dose. For trichloroethanol we can assume practically complete retention, elimination with the expired air being negligible.

It is therefore impossible to explain the difference in effectiveness between trichloroethylene and trichloroethanol in our experiments only by the higher elimination of trichloroethylene with the expired air. The higher depressant effect of trichloroethanol must also have contributed.

This high depressant effect of trichloroethanol is probably due to chemical binding of the substance with some receptors of neurones or other excitable cells. Some chemically closely related substances, e.g., chloral hydrate and alpha-chloralose, are still more effective depressants of the central nervous system. Alpha-chloralose, for example, evokes deep anaesthesia at $0.2 \mathrm{mM}$./kg., i.e., at one-tenth the dose of trichloroethanol. 
As trichloroethanol is a more powerful anaesthetic and hypnotic than trichloroethylene the question arises whether enough trichloroethanol is produced in an animal exposed to trichloroethylene to contribute substantially to the effects of the latter. As has been shown by many authors (Bartoníček and Souček, 1959, for animals; and Přerovská et al., 1958; Souček and Vlachová, 1960, for man in vivo), one-third to one half of the retained amount of trichloroethylene is metabolized to trichloroethanol and excreted in the urine as urochloralic acid. This quantity seems to be large enough to contribute to the pharmacodynamic and toxic effect of trichloroethylene.

There is no information on the ratio of free trichloroethanol to urochloralic acid in the tissues of guinea-pigs after exposure to trichloroethylene that would yield information on the rate of trichloroethanol conjugation. The problem has, however, been studied by Marshall and Owens (1954) in dogs and human subjects, to whom either trichloroethanol or chloral hydrate was given orally. The authors estimated analytically trichloroethanol and urochloralic acid in plasma and in urine. In dogs, conjugation of trichloroethanol to urochloralic acid proceeded quickly and was almost complete within two hours; but in humans, up to the eighth hour after ingestion, all the trichloroethanol in plasma was present as the free alcohol, i.e., no urochloralic acid was found. Even, however, in species where conjugation of trichloroethanol to urochloralic acid proceeds rapidly, central nervous depressant action may not be completely lost. Indeed, central nervous depression can be induced in rabbits by the oral administration of pure urochloralic acid or sodium urochloralate (Külz, I884). There is therefore little doubt that conjugation of trichloroethanol to urochloralic acid is reversible and that a portion of the trichloroethanol is present in vivo as such, due to equilibration between the free compound and its conjugate. Metabolic conversion of trichloroethanol to urochloralic acid does not seem to rule out an important role for trichloroethanol in trichloroethylene poisoning, as is assumed by some authors. For a review of this problem see the paper by Vyskočil and Polák (1963).

To conclude, the opinion of some clinical investigators that trichloroethanol is important in the pathogenesis of trichloroethylene poisoning has gained strong support from our experiments, in which the effects of both compounds, injected intraperitoneally in guinea-pigs, have been compared by several electrophysiological methods. No qualitative differences in their effects were found, but trichloroethanol was probably five to six times the more effective. This higher effectiveness cannot be explained by differences in the tissue concentration of the drugs; so, as one third to one half of the trichloroethylene retained by the animal is metabolized to trichloroethanol, it is probable that metabolic conversion to trichloroethanol contributes substantially to prolonging and even to deepening the depressant effect of trichloroethylene.

\section{REFERENCES}

Andersson, A. (1957). Acta. med. scand., 157, Suppl. 323.

Atkinson, R. S. (1960). Anesthesiology, 21, 67.

Bardoděj, Z. (1963). A study on absorption, metabolism, elimination and action of trichloroethylene. Dissertation, Charles Univ., Prague.

— and Krivucová, M. (1958). Cs. Hyg., 3, 268.

- and Vyskočil, J. (1956). Arch. Industr. Hlth., 13, 581.

Barnes, C. G., and Ives, J. (1944). Proc. roy. Soc. Med., 37, 528.

Barrett, H. M., Cunningham, J. G., and Johnston, J. H. (1939). f. industr. Hyg., 21, 479.

Bartoníček, V., and Souček, B. (1959). Arch. Gewerbepath. Gewerbehyg., 17, 283.

_ and Teisinger, J. (1962). Brit. F. industr. Med., 19, 216.

Beecher, H. K., and McDonough, F. K. (1939). F. Neurophysiol., 2, 289.

Bickford, R., and Faulconer, A. (196I). The Electroencephalogram in Anesthesiology. Thomas, Springfield, Illinois.

Bose, B. C., and Mukerii, B. (1944). Indian F. med. Res., 32, 65.

Butler, T. C. (1948). F. Pharmacol. exp. Ther., 92, 49.

- (I949). Ibid., 97, 84.

Chalupa, B., Synková, J., and Ševčík, M. (1960). Brit. F. industr. Med., 17, 238.

Courtin, R. F. (1955). Dallas med. F., 41, 613.

Defalque, R. J. (1961). Clin. Pharmacol. Ther., 2, 665.

Desoille, H., Pinchon, R. A., Lille, F., and Bourguignon, A. (1962a). Arch. Mal. prof., 23, 5. $\longrightarrow, \frac{}{653}$. Jans, M., and Bourguignon, A. (1962b). Ibid., 23,

Dhunér, K. G., Nordquist, P., and Renström, B. (1957). Acta anaesth. scand., I, 121.

Domino, E. F., and Ueki, S. (1959). F. Pharmacol. exp. Ther., $127,288$.

Forssman, S., Owe-Larsson, A., and Skog, E. (1955). Arch. Gewerbepath. Gewerbehyg., 13, 619.

Gibbs, F. A., Gibbs, E. L., and Lennox, W. G. (1937) Arch. intern. Med., 60, 154.

Guedel, A. E. (195I). Inhalation Anesthesia, 2nd ed. Macmillan, New York.

Horváth, M., and Mikiska, A. (1957). Pracov. Lék., 9, 22.

Klimková-Deutschová, E., Macek, Z., and Roth, B. (1959). Cas. Lék. Ces., 98, 1213.

Králová, H., Mikiska, A., and Pařizek, O. (1957). Pracov. Lék., 9, 44 .

Külz, E. (1884). Z. Biol., 20, I 57.

Mallach, J. F., Marquardt, G. H., and Werch, S. C. (1943). Amer. Heart $\mathcal{F}$., 26, 377.

Marhold, J. (1953). Laboratory report VÚOS RybitviPardubice. Cited by Souček and Vlachová (1959).

Marshall, E. K., Jr., and Owens, A. H., Jr. (I954). Bull. fohns Hopk. Hosp., 95, I.

Martin, J. T., Faulconer, A. Jr., and Bickford, R. G. (1959). Anesthesiology, 20, 359.

Massignan, L., and Picotti, G. (1955). Atti XX Congr. Med. Lavoro, Padova.

Medek, V. (1958). Pracov. Lék., 10, 135. 
Mikiska, A. (1960). Arch. Gewerbepath. Gewerbehyg., 18, 286. - (1962). Z. Präv. Med., 7, 283.

- (1963). Cs. Fysiol., 12, I51.

- and Mikisková, H. (1964). Activ. nerv. sup. (Praha), 6, 56.

Mikisková, H. (1960). Arch. Gewerbepath. Gewerbehyg., 18, 300.

- and Mikiska, A. (1960). Ibid., 18, 310.

- and - (1962). Int. Arch. Gewerbepath. Gewerbehyg., 19, 68.

Okuma, T., Shimazono, Y., and Narabayashi, H. (1957). Electroenceph. clin. Neurophysiol., 9, 609.

Orth, O. S., and Gillespie, N. A. (1945). Brit. F. Anaesth., 19, I6I.

Ostlere, G. (1953). Trichloroethylene Anaesthesia. Livingstone, Edinburgh and London.

Owens, A. H., Jr., Marshall, E. K., Jr., Broun, G. O., Jr., Zubrod, C. G., and Lasagna, L. (1955). Bull. Fohns Hopk. Hosp., 96, $7 \mathrm{r}$.

Paykoç, Z. V., and Powell, J. F. (I945). F. Pharmacol. exp. Ther., 85, 289.

Picotti, G., and Brugnone, F. (1962). Folia med. (Napoli), 45, 993.

Powell, J. F. (1945). Brit. F. industr. Med., 2, I42.

Přerovská, I., Srbová, J., and Stýblová, V. (1958). Pracov. Lék., 10, 417.
Roth, B., and Klimková-Deutschová, E. (1964). Cs. Neurol., $27,40$.

Roubíček, J. (1959). Clinical Electroencephalography. SZN, Praha.

Rubino, G. F., Scansetti, G., and Trompeo, G. (1949). Lav. umano, 11, 49.

Schlag, J., and Brand, H. (1958). Electroenceph. clin. Neurophysiol., 10, 305.

Schneider, J. (1954). Rev. neurol., 91, 428.

Serra, C., and Ambrosio, L. (I96I). L'elettroencefalogramma in Medicina del lavoro. (Quaderni di Acta neurologica $X X I)$, Naples.

Souček, B., and Vlachová, D. (1954). Pracov. Lék., 6, 330. and - (1959). Ibid., 11, 457.

- and - (1960). Brit. F. industr. Med., 17, 60.

Stentiford, H. B., and Logan, C. J. H. (1956). Lancet, 2, 659.

Stýblová, V. (1965). Diagnostická kriteria v prumyslové neurologii s hlediska prevence. SZN, Prague.

Vyskočil, J., and Polák, B. (1963). Vnitřni Lék., 9, 860.

Waters, R. M., Orth, O. S., and Gillespie, N. A. (1943). Anesthesiology, 4, I.

Wilson, F. N., Johnston, F. D., and Kossmann, C. E. (1947) Amer. Heart F., 33, 594 .

Woodard, G., Lange, S. W., Nelson, K. W., and Calvery, H. O. (194I). F. industr. Hyg., 23, 78. 